\title{
The Discussion of Possible Savings based on the Efficiency Argument in the Smallest Municipalities? The Case Study of the Vysočina Region $^{1}$
}

\author{
BARBORA BUREŠOVÁ AND STANISLAV BALÍK
}

\section{Sciendo}

Politics in Central Europe (ISSN: 1801-3422)

Vol. 15 , No. 2

DOI: $10.2478 /$ pce-2019-0020

\begin{abstract}
The unique municipality structure in the Czech Republic is one of the most interesting research topics in the Czech political space. The large number of municipalities with less than 1,000 or less than 500 inhabitants causes differences between Czech municipalities. There are differences in economic factors, differences in the development of municipalities, among other. All of these differences are discussed by experts, researchers and politicians in term of the efficiency of the smallest municipalities. The term 'efficiency' is used as the benchmark for a successful or an unsuccessful government. This research evaluates the argument of efficiency presented by Deborah Stone (2002). This argument was applied to the case of Kraj Vysočina, one of the regions with the largest number of the smallest municipalities in the Czech Republic. We analysed the selected argument of efficiency - economies of scale. Based on our quantitative analysis we have confirmed that evaluating municipalities through the prism of the economies of scale argument is not a good measurement of the efficiency of municipal government. The argument of efficiency is more complex and we cannot view it only in economics terms.
\end{abstract}

Keywords: Efficiency, Economies of scale, Czech local policy, municipality, municipality's costs

1 This article was written at Masaryk University with the support of the Specific University Research Grant provided by the Ministry of Education, Youth and Sports of the Czech Republic. 


\section{Introduction}

Democratic political systems should support a plurality of power, not homogeneity. However, while the horizontal dimension of the separation of powers (legislative, executive, judicial) is fully accepted, the vertical dimension (the difference between the central state administration and local authorities) is not regarded as necessary. Nevertheless, in democracies this is a vital moment. Despite differences between countries (there are a number of different degrees of self-government and the extent of their powers varies), the rights of local communities to self-govern has been one of the essential characteristics of modern democracies since the 19th century. However, genuine self-government cannot be attained by simply dividing the country into a large number of units. Successful self-government requires that each autonomous political community (defined as a territorial community with a sense of its own unique identity) is able to foster dialog and political discussion within the municipality.

In this case, we face the problem of being able to accurately identify a cohesive local polity. This probably explains why there is such a large variety of low-level local government structures in Europe.

According to the Czech Statistical Office, there are 6,258 municipalities in the Czech Republic. About $23 \%$ of these (1,440 municipalities) are home to 199 or fewer residents. The largest group consists of municipalities with populations of between 200 and 499 people; there are 2,000 municipalities in this group. Together, these two categories of the smallest municipalities make up 54.97\% of the total number of municipalities in the country (CSO 2017). The large number of small municipalities leads to the argument that their number and small size cause problems for the state budget (OECD 2016:113). The advantages (for example, greater identification with the local government) are not discussed.

How can we explain such a large number of small municipalities? Some guidance may be found in the historical development of urban structures. Czech villages are known for their cultural separation and their relative physical closeness, due to the colonisation of historic landscapes. During the colonisation process, the residents of territorial communities formed distinct identities. As pointed out by Hornek (2016: 46), the Czech Republic is home to the highest percentage of small municipalities in Europe, while the number of municipalities (not settlements), is steadily decreasing in the European context.

These trends are pointed out in tables 1 and 2. In the first table we see the evolution of the number of municipalities from 1921 to 2017. The number of municipalities has always been very high in Czech territories. An exception occurs during the 1970s and 1980s when, due to the communist regime and European trends causing the amalgamation of municipalities (Hornek 2016: 27), the number of municipalities decreased. However, the number of municipalities increased again in the 1990s. In the last two years the number of municipali- 
ties has stabilised at 6,258. Even so, the number of municipalities in the Czech Republic compared to the European context is very high. In table 2 we see the structure of communities in selected European countries. We find a similar structure of municipalities only in France or Slovakia, not only because of the large number of municipalities, but also because of the prevailing number of municipalities with fewer than 5,000 (or 1,000) inhabitants (Hornek 2016: 31). Even so, the number of municipalities in the Czech Republic compared to the European context is very high.

Obviously, the high number of small municipalities cannot be explained only by historical reasons for fragmentation of the Czech municipal structure. The key factor was the communist regime and its pressure on the amalgamation of the municipalities. This pressure peaked in the 1980s, shortly before the end of the communist regime. The period following the democratic transformation and the new democratic regime (in 1989 and 1990) was characterised by the effort to be as different from communist regime as possible. In general, the consequences at the local level were a renewal of the self-government of municipalities and the freedom for local communities to apply for their self-government. From the view of the small amalgamative municipalities, the argument for their separation was clear: the amalgamation was an anti-democratic tool used by the communist regime and we have to avoid it. Based on this, the result was the increased number of municipalities and for any further development impossibility to merge the municipalities. In this context, the amalgamation of municipalities has a different meaning (anti-democratic behaviour) in the Czech Republic in comparison with other countries.

Table 1: Development of the number of municipalities 1921-2017

\begin{tabular}{|c|c|c|c|c|c|c|}
\hline Year & 1921 & 1950 & 1970 & 1980 & 1989 & 1993 \\
\hline Number of municipalities & 11,417 & 11,459 & 7,509 & 4,778 & 4,120 & 6,196 \\
\hline Year & 2001 & 2010 & 2013 & 2015 & 2016 & 2017 \\
\hline Number of municipalities & 6,258 & 6,245 & 6,253 & 6,253 & 6,258 & 6258 \\
\hline
\end{tabular}

Source: Hornek 2016: 46; CSO 2015, 2016, 2017 
Table 2: The structure of municipalities in selected European countries

\begin{tabular}{|c|c|c|c|}
\hline Country & $\begin{array}{l}\text { The number of } \\
\text { municipalities } \\
\text { (in 2007) } *\end{array}$ & $\begin{array}{l}\% \text { of municipalities } \\
\text { with less than } 5,000 \\
\text { inhabitants * }\end{array}$ & $\begin{array}{l}\% \text { of municipalities } \\
\text { with less than } 1,000 \\
\text { inhabitants ** }\end{array}$ \\
\hline France & 36,683 & 95 & 77 \\
\hline Germany & 12,312 & 77 & - \\
\hline Spain & 8,111 & 85 & 61 \\
\hline Italy & 8,101 & 71 & 24 \\
\hline Czech Republic & 6,249 & 96 & 80 \\
\hline Hungary & 3,175 & 91 & 54 \\
\hline Romania & 3,173 & 35 & 2 \\
\hline Slovakia & 2,891 & 95 & 68 \\
\hline Switzerland & 2,785 & 89 & - \\
\hline Poland & 2,478 & 25 & 0 \\
\hline Austria & 2,357 & 91 & - \\
\hline Greece & 1,034 & 53 & - \\
\hline Belgium & 589 & 14 & - \\
\hline Latvia & 527 & 91 & 32 \\
\hline Netherlands & 443 & 2 & 0.2 \\
\hline Great Britain & 437 & 0 & 0 \\
\hline Norway & 431 & 55 & 4 \\
\hline Finland & 416 & 52 & 5 \\
\hline Sweden & 290 & 4 & 0 \\
\hline Bulgaria & 264 & 11 & 0 \\
\hline Estonia & 227 & 80 & 9 \\
\hline Slovenia & 210 & 48 & 3 \\
\hline Denmark & 98 & 3 & 0 \\
\hline Lithuania & 60 & 2 & 0 \\
\hline
\end{tabular}

Source: Hornek 2016: 31; Swianiewicz 2002: 25

* Source Hornek 2016: 31; List of countries was taken from this publication

** Source Swianiewicz 2002: 25; This publication does not work with some countries, so in the table this is noted with: "-".

In this respect, small villages are an interesting subject for research into municipal politics in the Czech Republic. We can include the phenomenon of

336 The Discussion of Possible Savings based on the Efficiency Argument... Barbora Burešová and Stanislav Balík 
small municipalities in the Czech Republic in research dedicated to the size of municipalities in general. Research dedicated to the size of settlements is a widespread issue, which is studied by authors across the scientific community. The size of the municipalities is not only of interest to political scientists but also to economists, sociologists, etc (Hornek 2016: 26). Important milestones in this research area include the publication written by P. Swianiewicz (2002) which focuses on the size of municipalities in Central and Eastern Europe, as well as the theoretical principles defined by M. Keating (1995) for considering the optimal size of the municipality. The aim of these debates is mostly to provide arguments for merging municipalities, which is not our goal. What these texts have in common is a focus on finding effectiveness, efficiency or optimalisation. This is an additional aim of this text.

In this study we focus on the effectiveness of the smallest municipalities in the Czech Republic. The effectiveness argument is based on the theoretical concept of policy paradox presented by Deborah Stone (2002). The aim of this article is to introduce the real functions of the smallest municipalities in the Czech Republic and analyse the effectiveness of the selected argument.

\section{Efficiency argument by Deborah Stone}

"Achieving an objective for the lowest cost" is the simple goal of efficiency (Stone 2002: 61). With this objective we make decisions in matters of everyday life. We pursue the same objective in political decision-making as well as in decisions by local authorities. Perhaps in local decision making we see the efficiency argument at work and expect the decision-making of experts to be more rational and correct more often than in everyday life.

In the case of political decision making, the challenge is to make decisions efficiently and we encounter the so-called 'policy paradox'. Based on the policy paradox and efficiency argument presented by Deborah Stone, we see that the major problem in political decision making is that it is not the same as making economic decisions (Stone 2002: 70). Even in economic decision making it is sometimes difficult to observe the efficiency argument. Furthermore, decision making is more complicated in the political arena. Therefore, what problems and challenges face policy makers and how do we define efficiency in a political environment?

According to Stone, the efficiency argument in the political setting is based on the 'ideal meant to guide how society chooses to spend its money or allocate its resources in order to get the most value' (Stone 2002: 65). In other words, efficient behaviour will get maximum benefits out of given inputs. However, Stone notes that political decisions are complicated by obstacles thrown up by outputs as well as inputs. In the case of inputs, we have to ask three basic questions: How can we count inputs (e.g. labour costs) that are simultaneously outputs to somebody 
else (e.g. jobs for the local community)? How should we decide which of the many benefits/outputs of any input to count in the equation? How should we count the virtually unlimited opportunity costs of resources used as inputs? (Stone 2002: 67). There are also three possible problematic questions we need to address when considering outputs: Who determines what is the correct output goal, or the objective of a program? How should we value and compare multiple objectives? How do different objectives or outputs benefit different constituencies? (Stone 2002: 67). These issues could be summarised in two simple questions: Who and what are important? (Stone 2002:65). The answer to these questions can have multiple correct answers. Answers to these questions are political claims, the efficiency of which can differ based on who is looking at the problem. (Stone 2002: 65).

Generally, in the context of the theory of markets there is a consensus that efficient decisions are those based on a voluntary basis and on full awareness (the subjects are fully informed). However, the market environment faces several challenges due to these two principles. The first challenge is a market failure in the context of the principle of voluntary exchange. In the context of the market there are market failures, which make the behaviour in the market inefficient. The second challenge is the principle of full awareness (complex information). The information is not always easily accessible. People are often not willing to pay or meet high costs to acquire information. We also face the problem of misunderstood information (Stone 2002: 72). These challenges can be transferred to the political environment. Voluntary behaviour in the political environment is very close to coercion (e.g. the laws of the society ${ }^{2}$ ). The society is influenced by traditions, family habits and cultural practices which enter into the everyday decisions and behaviour of both individuals and the entire society. According to Stone, the principle of voluntary behaviour within the political community is very questionable. Equally problematic is observing the principle of full awareness in the polis. Within the polis information is always incomplete (we never have all the information). Information is always interpreted (not the original) and information is always submitted within a certain context and each person can understand the information differently. At the same time, we cannot predict the long-term development of that information. These are all examples of why decisions cannot always be efficient in the polis (Stone 2002: 77). The third challenge we face in the polis is the tension between the individual and social welfare. Here we see the misunderstanding of public good (well-being), which views the public good as a summary of individuals goods. However, just as in the market environment, where the market does not operate according to microeconomic theory, the polis does not operate according to sweeping political theory. Individuals are influencing each other, and often social well-being is

2 The law always provides rules of behaviour and sanctions applicable to infringements of the law. 
a dependent variable that influences individual well-being. Social and individual well-being is influenced by many different factors and variables.

It is very difficult to find solutions to political problems. Often we hear the argument that any given solution is the only one that can achieve a particular goal. In this argument, we often hear the word 'efficient'. However, as Deborah Stone points out in her book The Paradox of Policy, talking about finding a political tool or mechanism is very misleading. Political problems are very complex and they are not permanent. Stone argues that ' $(p)$ olicy actions, though, are really ongoing strategies for structuring relationships and coordinating behaviour to achieve collective purposes' (2002: 261). The correct solution would therefore be to find a strategy that can be followed and to go with it.

Often, the economic arguments and solutions to political problems based on market rules and strategies are presented as the correct political tools and as the only right solutions. These arguments are solely associated with efficiency. In The Paradox of Policy, Stone gives an example of this argument in matters of racial equality in the United States. Stone says that J. Kennedy's argument for racial equality stood on the argument of efficiency and economic prosperity. He also stressed the morality of these decisions, which was unique. In order to properly understand the efficiency argument, one must be able to measure its effects. As Stone says, efficiency is always supported by the arguments of inputs and outputs, statistics, etc. (2002: 399). If we analyse the efficiency argument, or criticise it, we have to take into account that actual efficiency is not the goal. Efficiency is only an 'indicator' of how to best achieve a goal. Based on this, in analysing the efficiency argument, we have to ask the question: 'Do I accept the goal that the argument assumes?' (Stone 2002:400).

In the case of the research on small municipalities, the economic arguments mentioned by Stone are the most common arguments used to evaluate the inefficiency of small municipalities. Based on these economic arguments, some authors argue that it is necessary to merge the municipalities, etc. In this paper we will deal with these arguments. In the introduction we mentioned author M. Keating and the four principles on which he argues in favour of merging small municipalities. These principles are also used in the debate about the efficiency of municipalities. One of the principles, which is also the default for this text, is called 'economic effectivity' (economic efficiency). This principle is based on the theoretical assumption of economies of scale (the size of the municipality decreases the cost of local government activities and local services). However, according to Keating, this principle is not entirely clear because these assumptions have not yet been empirically confirmed (Hornek 2016: 36).

The focus of this text is on the economic efficiency argument (the argument in terms of economies of scale) and finding an empirical answer. The aim is not to confirm this argument generally, but to find at least a partial response to empirical data samples. The Czech environment seems to be a good area for 
this analysis because the country has long discussed the effectiveness and efficiency of public administration, especially the effectiveness and efficiency of local governments. The starting point for this discussion is the OECD report presented in 2016.

\section{OECD and the inefficiency argument in the public sector - a small village in the Czech Republic}

The inefficiency of the public sector due to the existence of very small municipalities and the large-scale fragmentation of local government in the Czech Republic was analysed by the Organisation for Economic Co-operation and Development (OECD). In a report about the development (also economic) of the Czech Republic in $2016,{ }^{3}$ one of the key findings in the field of public administration is inefficiency in local government. The OECD mentions the specific structure of local government in the country. The OECD analysis showed that fragmentation and a very large number of very small municipalities in the Czech Republic causes not only economic inefficiency (for example, high costs of salaries), but also inefficiency in services (health, education, etc.) (OECD 2016: 113). The OECD also criticised the incomplete structure of districts and regions (OECD 2016: 114). Problems caused by the small size of municipalities according to the OECD include: the high costs of small municipalities to participate in a voluntary association of municipalities, the loss of economies of scale (especially in the area of administration, with the resulting lack of remaining funds for other services), insufficient capacity and the highly difficult task municipalities face in recruiting educated and experienced staff for public administration, the low level of investments (in municipalities with less than 1,000 inhabitants investments are $20 \%$ lower compared with municipalities with 1,000-5,000 inhabitants).

As a solution to these problems, the OECD suggests the amalgamation of municipalities. The OECD cites examples of European countries (Great Britain, Ireland, Portugal) where the amalgamation of municipalities has been successfully implemented. However, the OECD also notes that in some countries the amalgamation did not lead to a reduction in costs (although it did lead to an increase in the quality of services (OECD 2016: 118). As another example of how to solve the problem, the OECD presents the practice of Italy and Hungary, where small communities are required to cooperate in the administration of selected services (OECD 2016: 119).

3 The report of 2018 is mainly focused on the possibilities in health development in the country. The question of local government is only mentioned minimally. The report notes the need for further efforts to develop and promote the shared technical support to municipalities and further it is necessary to introduce rules for municipal funding, namely the rules relating to public debt (OECD 2018: 62-63). These recommendations were established in 2016. 
Also, the OECD recommends that larger municipalities should take over the administration of some services, including education, health and social services. Other services can, according to the OECD, be provided using e-Government (OECD 2016: 119).

Based on this criticism, we will analyse the possibilities of savings in local government expenditure. The savings will be studied based on the argument of economies of scale. However, it is necessary to take into account the specifics of Czech local government and its practical functioning.

\section{Specifics of Czech municipal government and Czech municipal financing}

The OECD report is very general, and in many criteria overlooks the specifics of Czech municipalities. To look deeply at this problem, author Jakub Hornek in his publication Politické dopady zadlužování malých obcí v České republice: prípadová studie Karlovarského kraje 2010-2014 focuses on the issue of small communities and their problems with financing. Hornek notes that small municipalities often do not establish any schools or medical or social centres (Hornek 2016: 56). Based on Hornek's argument, the OECD's facts could then seem nonsensical. This contradiction is caused primarily by the fact that the OECD and Hornek define small municipalities differently, with Hornek using a benchmark of 500 inhabitants and the OECD using 1,000. Hornek's definition corresponds better with the Czech environment. Furthermore, the Czech Statistical Office categorises small municipalities as even smaller - as municipalities with up to 199 inhabitants (CSO 2017).

The characteristics of small municipalities in the Czech Republic are not clear, according to Hornek. Determining the point at which a municipality is considered small and at which point it is considered larger is very difficult. In this article, we will work with the lowest level according to the CSO (municipalities with 0-199 inhabitants). It is necessary to mention that population size is not the only indicator here. Other indicators used in research in this area are the municipality area, services provided by the municipality, etc. However, in this research we are inclined to divide the municipalities by population.

Among the municipalities are many differences in the quantity and quality of the functions provided. Small municipalities always fulfil the political and economic ${ }^{4}$ functions. These two functions are compulsory for the municipalities

4 According to Act no. 128/2000 Sb., municipalities have separate and delegated powers. Hornek uses categorisation from the publication Komunální politika (2009). According to this categorisation, municipalities can perform the following functions: safety (the establishment of municipal police, etc.), environmental (collection and disposal of waste, municipal purity, etc.), economic (finances and economy of the municipality, etc.), infrastructure (maintenance and management of roads, water supply, sewerage etc.), political (elections, the creation of municipal bodies, etc.), prognostic (approval of the development community, local and regulatory plan, etc.) and social (education, health, culture, etc.) (Balík 2009: 30-31). 
according to law. In the economic function, besides drawing up the budget, final accounts, etc., there is the possibility that municipalities will also establish trading companies, municipal companies and other entities. However, small municipalities face the problem of a lack of finance (and, among other things, perhaps a lack of motivation) to exploit these options (Hornek 2016: 56). The environmental, social and safety functions are often transferred to larger communities in a small municipality's vicinity. However, delegated social functions cause, for example, low cultural activities in small municipalities. Administering the infrastructure function might also be problematic for small municipalities. Infrastructure in these communities (e.g. - whether conditions of pavements or roads or access to larger municipalities) is mostly bad. This stems from insufficient financial investments, co-financing agreements and subsidies and from a lack of personnel (Hornek 2016: 57). The same problems are also seen in municipal development. The structure of small municipalities' populations is also problematic for development. Municipalities face very low natural population growth, high unemployment, lower average levels of education, among other problems (Hornek 2016: 58).

All these problems are related to the setting of municipal financing in the Czech Republic. Economic management of the municipalities is defined by the Constitution of the Czech Republic and the European Charter of Local Self-Government and various legal modifications. The basic legislation is Act no. 128/2000 Sb. o obcích and Act no. 250/2000 Sb. o rozpočtových pravidlech územních rozpočtů. Using an explanation of these two laws, we will introduce the basic parameters of the economic management of local governments in the country. Act no. 128/2000 Sb. presents the basic definition of the municipalities, their functions and separate and delegated powers. Among one of the most significant separate powers is the economic management of the municipality (Act no. 128/2000 Sb. \$ 38). Economic management is based on the budget, budgetary rules (Act no. 250/2000 Sb.) and other tax mechanisms, subsidies and transfers (Kruntorádová 2015: 59).Discussing the general economic management of Czech municipalities, Kruntorádová highlights the problem of financing delegated powers, as Act no. 128/2000 Sb. only mentions that the municipality will receive a contribution for this activity and the law does not address this issue further (2015: 61).

Budgets and management systems in the Czech reality correspond to the model of fiscal federalism. This model combines centralised management (state budget and state extra-budgetary funds) and decentralised management (self-budgets of municipalities and regions). Financial flows between these entities influence the budgets of each. According to Hornek, municipalities in the Czech Republic are 'generally self-sufficient, generating 70\% of their own incomes' (Hornek 2016: 70).

The basic function of the economic management of local governments is to manage according to the approved municipal budget. Municipal budgets must 
be based on the financial outlook of the municipalities. The goal of management is to maintain and develop municipal property. Municipal councils are responsible for the budgets. Act no. 250/2000 Sb. also establishes additional responsibilities of the municipalities (e.g. accounting) as well as control mechanisms and institutions (Act no. 250/2000 Sb.).

Municipal budgets consist of municipal incomes and expenses. Incomes are divided into tax (e.g. property taxes, income taxes, taxes from profits and capital gains, local taxes, fees, etc.), non-tax (e.g. incomes from the municipalities' own activities and payments of surpluses from organisations with direct relationships with the municipalities), capital (e.g. receipts from sales of tangible fixed assets) and subsidies (non-capital or capital transfers received). The expenses include common municipal expenses (e.g. expenditures on salaries, non-investment transfers to public entities, etc.) and capital expenses (investment purchases, investment transfers, etc.). At the end of each calendar year, the municipalities expose their revenue and expenditure accounts, which are a summary of the implementation of the budget (Hornek 2016: 72-79).

The issue of income depends on the size of the municipality's population. The following diagram of the distribution of tax within a budget reveals the tax revenues of municipalities.

\section{Chart 1: Diagram of distribution of budget tax determination}
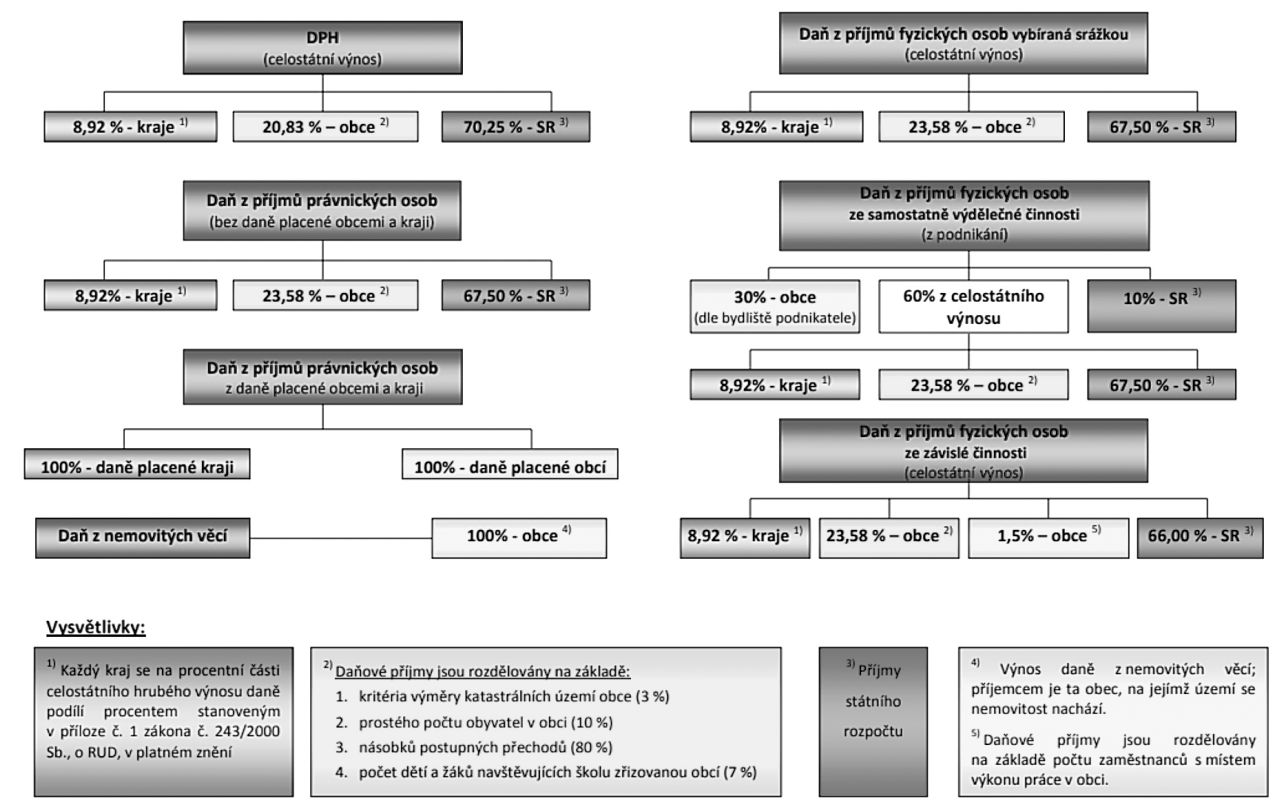

Source: Diagram of distribution of budget tax determination; Ministry of Finance in 2018 
The diagram shows that $10 \%$ of the income is determined by the number of inhabitants in the municipality. The population in the municipality is not reflected in multiples of gradual transitions (point three in the diagram). And this part of the tax determination comprises $80 \%$ of tax income. Here the smallest municipalities are at a disadvantage. The smallest municipalities (up to 50 people) do not benefit from a discounted rate. ${ }^{5}$

Additionally, this is the reason for the financial problems of the smallest municipalities.

\section{Methodology, research questions, and data collection}

In this text we assume the argument of economies of scale, which in this case mainly analyses the amount of municipal expenditure. For this reason, we focus on the expenditure side of the municipalities. The main premise is that the expenditures are composed of expenditures that could not be saved and those that could be saved, all in terms of economies of scale. As expenses that could not be saved, we consider the expenses that will remain in the municipal budget even after transferring its management to another municipality (either by joining in a voluntary association of municipalities or merging with other municipalities). Examples of such expenditures are expenditures on repairs, administration of roads, water supply, sewerage, lighting, etc. The second group of expenses comprises those that could be saved by transferring the management of the municipality to another entity. This group of expenses mainly includes costs associated with the activities of local government. Here we see expenses arising from the operation of the municipal authority, which could be spared if the municipal management is transferred to another municipality.

The argument of economies of scale says that with the growing size of the municipality, the amount of expenditures decreases. In this analysis we work with the assumption that the expenses are reduced, especially those that can be saved. ${ }^{6}$ In the whole analysis we will work with the breakdown of expenditures presented in the previous paragraph.

This article aims to introduce the real functioning of the smallest municipalities in the Czech Republic and, based on their example, analyse a selected argument of efficiency, i.e. the economies of scale. For our analysis and to fulfil the objective we determined the research question to be:

How much of the municipal budget is made up of expenditures that could be saved (in case of the smallest municipalities)?

5 Also for this reason we choose to categorise municipalities by population.

6 E.g. We do not expect that after transferring the management of the municipality to another municipality, or in the case of municipal mergering, spending will be lower on roads, pathways, water supply and sewerage. 
Based on the answer to this question we can determine what portion of spending by the smallest municipalities could be saved if their management was moved to another municipality. This answer will be discussed in the context of the efficiency argument. Based on the analysis, it will be possible to determine if the efficiency argument is possible to use in this research area. The paper will also include a discussion about whether we can talk about effectiveness in this context.

To answer the research question, we monitored expenditures of municipalities using their final revenue and expenditure accounts, within which municipalities specify their incomes and expenses (according to Act no. 250/2000 Sb. municipalities must follow the regulation of budget structure when drawing up their final accounts). This regulation defines in detail the rules for the presentation of income and expenditures in budgets (Decree no. 323/2002 Sb.). Based on this, in the municipal final accounts we found which expenditures and revenues were used for what purposes and determined which expenditures municipalities could save and which they could not. Municipalities are required to monitor the types of income and expenditures in terms of this classification: generic, sector, consolidation, source and transfer (Decree no. 323/2002 Sb.). For our purposes, the most important aspect to monitor is the sectoral classification. The sectoral classification divides revenues and expenditures into the types of activities from which income is derived and on which spending is applied. The sectoral classification does not include the income tax, subsidies and financing operations, which is not a limitation on our research. Budget structure defines the following sectors:

1. Agriculture, Forestry and Fisheries (e.g. the cost of municipal agricultural equipment, etc.)

2. Industrial and other sectors of the economy (e.g. maintenance of local roads, etc.)

3. Services for inhabitants (e.g. the operation of schools and health facilities, etc.)

4. Social Affairs and Employment Policy (e.g. the operation of a home for the elderly, etc.)

5. National Security and Legal Protection (e.g. municipal police and volunteer firemen posts, etc.)

6. General Public Administration and Services (e.g. spending on elections, referenda, municipal government, etc.) (Decree 323/2002 Sb.).

Based on this classification, we realise that sectors 1-5 are sectors that the smallest municipalities do not have (for example, elementary schools), or that in our breakdown belongs to expenditures that could not be saved (e.g. local roads). Sector 6 includes the expenses related to the activities of the municipal office and local government. Also, there are activities that could not be saved (e.g. 
the cost of elections). However, there is the section called Regional and Local Government, which in the case of municipalities is further specified in section no. 6171 Local Government Activities. This section includes the municipalities' own administrative activities. Also included are expenses from the social fund established for municipal employees, municipal office operation, etc. (Decree $323 / 2002 \mathrm{Sb}$.). In our research, we analyse this section because it includes expenses which could be saved in the case of merging the municipalities or in the case of joining a voluntary association of municipalities. ${ }^{7}$

In our research, we monitored the final account of the municipalities, their income and expenses, to present the real functioning of the smallest Czech municipalities. The expenditures will then focus on the sectoral breakdown, especially on section 6171 Local Government Activities. Finally, we compare the expenditure side of the village and their expenditure on Local Government Activities.

The research is based on quantitative data, and statistical indicators and methods are used for evaluation of the results.

\section{Data Collection}

The quantitative research works mostly with sample data, not the entire population (Field 2009: 31). For the purposes of this research, the municipalities of the Vysočina region were selected. Municipalities were selected only from one region in order to ensure socio-economic and historical similarities. The Vysočina region was chosen because it is home to the highest number of municipalities in the Czech Republic with a population of up to 199. The research works with 214 municipalities.

Data about the municipalities was collected from the database of the Czech Statistical Office. Data about the municipal budget was collected using the MONITOR tool produced by the Ministry of Finance. Final revenue and expenditure accounts of the municipalities were downloaded from the websites of individual municipalities. The final accounts were, where available, supplemented by annexes to the final accounts - primarily the final municipal budget measurements and the Statement for Assessing Implementation of the Budget of Local Governments, Voluntary Associations of Municipalities and Regional Councils. Data affecting the municipal budget was monitored for 2016 and 2017. Primarily, data for the year 2016 was used due to the completeness of the data. The reason is that in the data collection period (summer 2018), we assumed that not all municipalities had published the final account for the year 2017.

7 Here we have to point out the existing limit of this research. We are not able to divide the expenses directly into two categories (could be saved and could not be saved). These categories were created for the purposes of this research. 
The deadline for publication of the final account is not set by law. There is not a fixed deadline for the publication of the final account, so publication can be affected by a lengthy process of approval (Act no. 250/2000 Sb.). However, during data collection, despite an assumption to the contrary, we found that some municipalities do not electronically archive final accounts from previous years. Because of this the dataset was supplemented by information from $2017 .{ }^{8}$

The total number of municipalities of up to 199 inhabitants in the Vysočina region is 330 . The dataset consists of 214 municipalities. The number is lower due to the incompleteness and unavailability of necessary data from municipal websites. These data collection obstacles did not obstruct our research. This research takes into account possible weaknesses in terms of applicability to the entire country.

\section{Data analysis}

There are 704 municipalities in the Vysočina region. After the Středočeský Region, it is the region with the highest number of the smallest municipalities. Table 3 shows the municipality structure in Vysočina region. For example, there are no municipalities in the region with more than 100,000 inhabitants. The largest group of municipalities consists of villages with less than 199 inhabitants, and the second largest group consists of villages with less than 499 inhabitants.

\section{Table 3: Population structure in the Vysočina region}

\begin{tabular}{|c|c|c|c|c|c|c|c|c|c|c|}
\hline $\begin{array}{c}\text { less } \\
\text { than } \\
199\end{array}$ & $\begin{array}{l}200 \\
\overline{499}\end{array}$ & $\begin{array}{l}500 \\
\overline{999}\end{array}$ & $\begin{array}{c}1000 \\
\overline{-} \\
1,999\end{array}$ & $\begin{array}{l}2,000 \\
4, \overline{9} 99\end{array}$ & $\begin{array}{l}5,000 \\
\overline{9} \overline{9} 99\end{array}$ & $\begin{array}{c}10,000 \\
19, \overline{9} 99\end{array}$ & $\begin{array}{c}20,000 \\
49,999\end{array}$ & $\begin{array}{c}50,000 \\
\overline{9}, \overline{9} 99\end{array}$ & $\begin{array}{c}\text { over } \\
100,000\end{array}$ & total \\
\hline 331 & 208 & 98 & 36 & 14 & 9 & 4 & 3 & 1 & - & 704 \\
\hline
\end{tabular}

Source: CSO 2017

In this paper we analyse 214 municipalities. The smallest surveyed village has 15 inhabitants, the average is municipalities with 121.05 inhabitants. This value is not the best indicator of the distribution of the data (see histogram 1). A better indicator is the median and modus population (Field 2009: 38). The median value of the population in the surveyed municipalities is 120.5 .

8 In terms of information about income, expenditure and balance was also monitored in the budget for the year 2017. 


\section{Histogram 1: The population in the analysed municipalities}

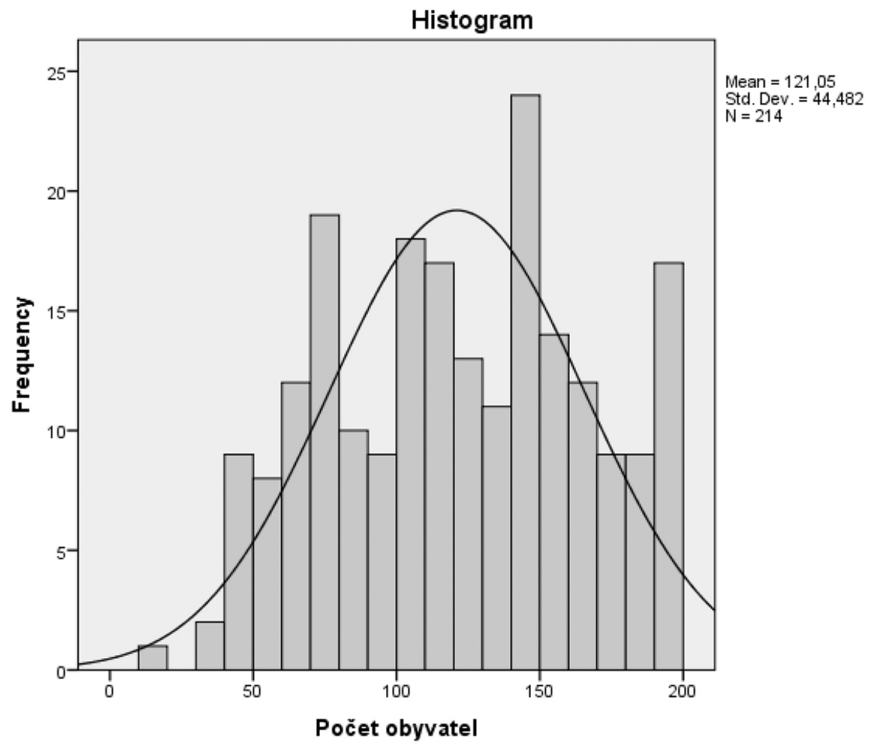

Source: own analysis

In the analysed municipalities we monitor the revenues and expenditures from 2016 and $2017 .{ }^{9}$ The average income of studied municipalities was 2,766,000 CZK. The average expenditure was $2,390,680 \mathrm{CZK}$. The average balance between revenues and expenditures in the reporting periods was positive; the average is a sum of 382,720 CZK. Table no. 4 clearly presents values and also modus and median.

Table 4: Revenue and expenditure of municipalities

\begin{tabular}{|c|c|c|c|}
\hline in thousand (CZK) & Expenses & Income & Balance \\
\hline Average & $2,390,680$ & $2,766,000$ & 382,720 \\
\hline Median & $2,011,000$ & $2,521,500$ & 375,000 \\
\hline Modus & $869,000^{\mathrm{a}}$ & $1,191,000$ & $303,000^{\mathrm{a}}$ \\
\hline Minimum & 348,000 & 539,000 & $-4,916,000$ \\
\hline Maximum & $1,087,100$ & $1,788,100$ & $1,232,700$ \\
\hline
\end{tabular}

a) Multiple modes exist. The smallest value is shown

Source: own analysis

9 Examined each year, depending on the publication of the final account. In this research we do not take into account the differences between years. Based on the research design we do not expect significant changes in individual years. Possible differences are not limiting for this research and do not influence the final results. 
As mentioned previously, average values are not an entirely accurate indicator. For example, when looking at the values of balance, it would seem that the surveyed municipalities manage budgets with positive balances. It seems that their budgets are not in deficient. However, in the sample, 49 municipalities had a budget deficit. It is important to note that only four municipalities have a long-term budget deficit. ${ }^{10}$ In other municipalities, a budget deficit was found only in one year.

\section{Local Government Activities - Analyses of Expenditures}

The average value of expenditures on local government activities in selected municipalities is $404,940 \mathrm{CZK}$. The median value is $303,500 \mathrm{CZK}$. If this number is multiplied by the total number of municipalities with less than 200 inhabitants in the whole Czech Republic, we get the estimated total number of issued expenditures. The total estimate is $437,040,000 \mathrm{CZK}$ issued for the purposes of local government. This number is certainly not small. And if we look at the share of this expenditure in total, the expenditure on local governmental activities constitutes $20.1 \%$ of total expenditures.

\section{Table 5: Expenditure - Local Government Activities}

\begin{tabular}{|c|c|}
\hline in thousand (CZK) & Local Government Activities \\
\hline Average & 404.94 \\
\hline Median & 303.50 \\
\hline Modus & $135^{\mathrm{a}}$ \\
\hline Minimum & 20 \\
\hline Maximum & 2375 \\
\hline
\end{tabular}

a) Multiple modes exist. The smallest value is shown Source: own analysis

The average may be distorted due to the distribution of the data (see Histogram 2 and 3). The most common group represented consists of municipalities with expenditures for local government activities within the range of up to 500,000 CZK (in Histogram 3, the share of expenditures on local government activities is most often up to $20 \%$ of total expenditures). The overall average increases exemptions, and we can cite as an example the municipality Kostelní Myslová (expenses for local government activities accounted for 1,151 million CZK). In this case, the majority of spending on local government activities was used to buy equipment for biomass processing, which is a one-time (not regular)

10 Municipalities Březská, Stone, Racice Ždírec had budget deficits in the period from 2015 to 2017. 
expense. In the municipality Trpišovice, which had a sample of the highest expenditures on local government activities, the highest component of expenditures was under the category of Purchase of Other Services. Unfortunately, these expenses were not itemised in this municipality.

\section{Histogram 2: Expenditure - Local Government Activities}

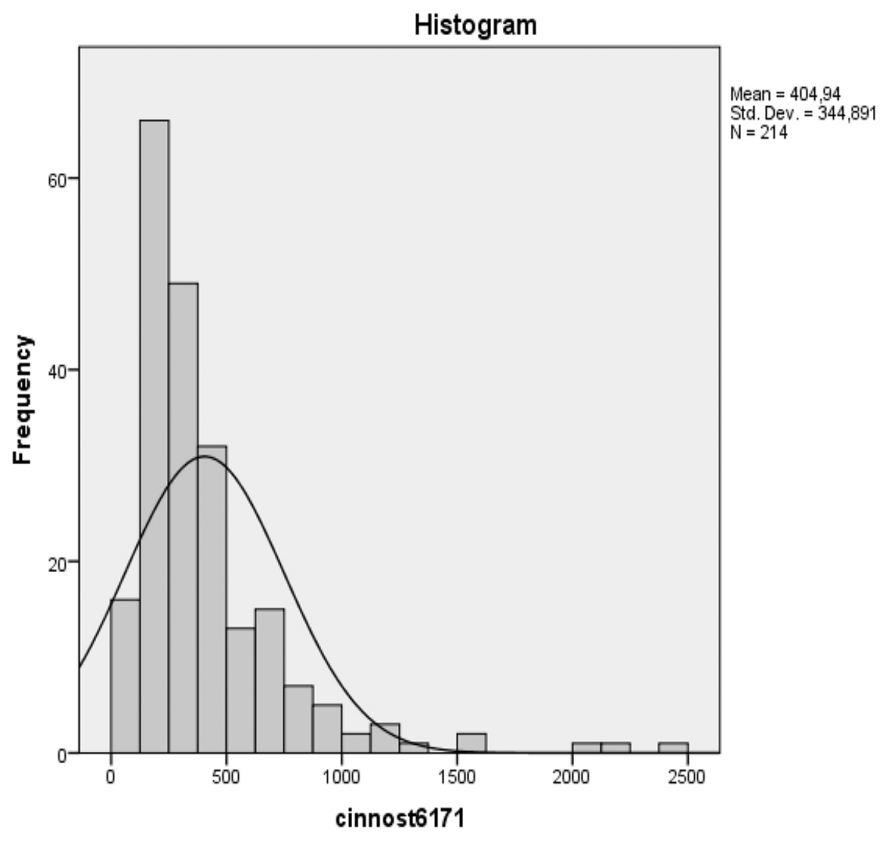

Source: own analysis

Table 6: The share of expenditures on Local Government Activities of total expenditures

\begin{tabular}{|c|c|}
\hline$\%$ & Share \\
\hline Average & 20.1 \\
\hline Median & 16.1 \\
\hline Modus & $0.73^{\mathrm{a}}$ \\
\hline Minimum & 0.73 \\
\hline Maximum & 79.28 \\
\hline
\end{tabular}

a) Multiple modes exist. The smallest value is shown Source: own analysis 
Histogram 3: The share of expenditures on Local Government Activities of total expenditures

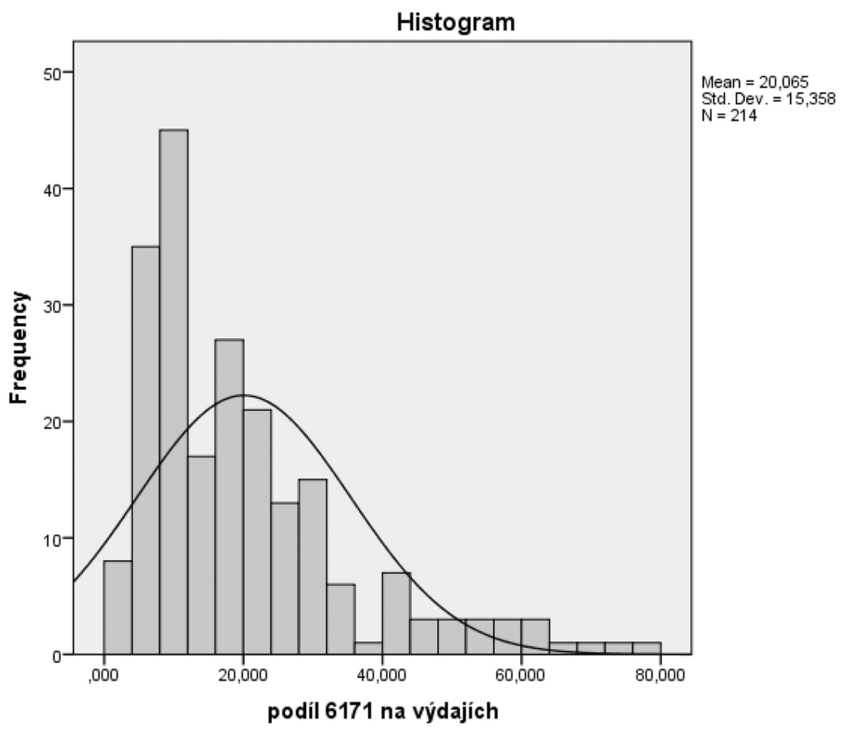

Source: own analysis

The most common spending on local government activities ranges from 101 to $300,000 \mathrm{CZK}$, which we found in 94 cases (44\%). Overall, expenditures by municipalities on local government activities was less than 500,000 CZK and constitutes $76.2 \%$ of total expenditure in the Vysočina region. The frequency of other expenditures on local government activities is presented in table 7 .

Table 7: The frequency of expenditures on Local Government Activities

\begin{tabular}{|c|c|c|c|}
\hline & Frequency & \% & Cumulative \% \\
\hline $\mathbf{0 - 5 0 ~ 0 0 0 ~}$ & 2 & 0.9 & 0.9 \\
\hline $\mathbf{5 1 0 0 0 - 1 0 0 ~ 0 0 0}$ & 10 & 4.7 & 5.6 \\
\hline $\mathbf{1 0 1 0 0 0 - 2 0 0 ~ 0 0 0}$ & 44 & 20.6 & 26.2 \\
\hline $\mathbf{2 0 1 0 0 0 - 3 0 0 ~ 0 0 0}$ & 50 & 23.4 & 49.5 \\
\hline $\mathbf{3 0 1 0 0 0 - 4 0 0 ~ 0 0 0}$ & 32 & 15.0 & 64.5 \\
\hline $\mathbf{4 0 1 0 0 0 - 5 0 0 ~ 0 0 0}$ & 25 & 11.7 & 76.2 \\
\hline $\mathbf{5 0 1 0 0 0 - 6 0 0 ~ 0 0 0}$ & 11 & 5.1 & 81.3 \\
\hline $\mathbf{6 0 1 0 0 0 - 1 0 0 0 ~ 0 0 0}$ & 29 & 13.6 & 94.9 \\
\hline $\mathbf{1 0 0 0 0 0 0}$ and more & 11 & 5.1 & 100.0 \\
\hline Total & 214 & 100.0 & \\
\hline
\end{tabular}

Source: own analysis 


\section{Final discussion}

The analysis of the data can be used to answer the research question. Analysed municipalities in the Vysočina region spent on average $20.1 \%$ of their total expenditures on local government activities. In this paper we analysed this type of expenditure as the kind of expenditure that could be saved in the case of a municipality merging or in the case of a municipality joining a voluntary municipal association. The median value is about $16.1 \%$ of total expenditures. Overall, the smallest municipality in the period generally had no problems with debt (with the exception of four cases). Mostly, income outpaced expenditures in studied municipalities. These results show the financial reality of the smallest municipalities in the Czech Republic. However, we have to take into account the limit of this research. We have to point out that our conclusions were tested on the case of Vysočina region only. Furthermore, as we have mentioned above, the division to the expenses which could be and could not be saved were created only for the purposes of this research.

If we want to evaluate the efficiency argument within the context of economies of scale, we encounter two basic problems mentioned by Deborah Stone. First, who decides what is an efficient amount? And secondly, what counts as efficient/effective (Stone 2002: 65)? A standard for what constitutes an efficient amount or what is considered the best cost for local government activities does not exist. There is no body or authority that would be able to determine such a standard. In addition, there is no definition of what constitutes expenditures on local government activities. The aim of economies of scale is to save the greatest amount of economic resources. When analysing this argument, we should keep this in mind. Even here, however, we encounter the above two problems. The found values and presented results (only) empirically describe the reality of observed municipalities. Theoretically, in the case of transferring the administration of the smallest municipalities to a larger municipality, or in the case of merging municipalities, 437,040,000 CZK could be saved in the Czech Republic. However, it is necessary to point out the limits of this saving. In section no. 6171, local government activities could be included in the expenditure on wages (e.g. part time jobs as accounting, technical services personnel, etc.). Some municipalities could use this section as a summary of all expenditures on municipal government. Here we face the previously mentioned problem that in the smallest municipalities there is a lack of human capacity and, for example, accounting is not provided by experts. These expenditures would likely not have disappeared in the case of merging, etc. This number is therefore a theoretical estimate.

Finally, this research confirms Keating's scepticism about the empirical analysis of the argument of economies of scale. In the empirical study we face the limits of the plurality and uniqueness of studied objects and, what's more, 
in the Czech reality, the great differentiation between municipalities. And last but not least, we also face the problem of how to determine what is efficient/ effective. At the same time, this analysis showed the existence of certain types of expenditures that should be studied further in order to find ways to better allocate these expenses.

\section{References}

Act no. $128 / 2000 \mathrm{Sb}$.

Act no. 250/2000 Sb.

Balík, Stanislav (2009): Komunální politika: obce, aktéri a cíle místní politiky. Praha: Grada Politologie. ISBN 978-80-247-2908-4.

CSO 2015. Malý lexikon obcí České republiky 2015. Český statistický úřad. Available at: https:// www.czso.cz/csu/czso/maly-lexikon-obci-ceske-republiky-2015 (30 July 2018)

CSO 2016. Malý lexikon obcí České republiky 2016. Český statistický úřad. Available at: https:// www.czso.cz/csu/czso/maly-lexikon-obci-ceske-republiky-2016 (30 July 2018)

CSO 2017. Malý lexikon obcí České republiky 2017. Český statistický úřad. Available at: https:// www.czso.cz/csu/czso/maly-lexikon-obci-ceske-republiky-2017 (30 July 2018)

Decree no. 323/2002 Sb.

Field, Andy (2009): Discovering Statistics Using SPSS. 3rd Edition. Sage Publications, London

Hornek, Jakub (2016): Politické dopady zadlužování malých obcí v České republice: př́ípadová studie Karlovarského kraje 2010-2014. Praha: Sociologické nakladatelství (Slon). Studie. ISBN 978-80-7419-242-5.

Kruntorádová, Ilona (2015): Politické aspekty financování českých měst. V Praze: Karolinum. ISBN 978-80-246-2744-1.

Ministry of Finance. Ministry of Finance of the Czech Republic - Diagram of distribution of budget tax determination in 2016. Available at: https://www.mfcr.cz/cs/verejny-sektor/uzemni-rozpocty/prijmy-kraju-a-obci/zakladni-informace/2016/schema-rozdeleni-rozpoctoveho-urceni-dan-23647 (4 September 2018).

Ministry of Finance. Ministry of Finance of the Czech Republic - App Monitor. Available at: https://monitor.statnipokladna.cz/2018/ (18 September 2018).

OECD 2016. OECD Economic survey: Czech Republic. Available at: https://www.mzv.cz/oecd.paris/cz/zpravy_udalosti_aktuality/oecd_hospodarsky_prehled_ceske_republiky.html a https:// read.oecd-ilibrary.org/economics/oecd-economic-surveys-czech-republic-2016_eco_surveys-cze-2016-en\#page118 (14 August 2018).

OECD. 2018. OECD Economic Surveys: Czech Republic 2018. (cit. 15. 8. 2018). Available at: https:// www.oecd-ilibrary.org/economics/oecd-economic-surveys-czech-republic-2018_eco_surveys-cze-2018-en)

Stone, Deborah (2002): Policy paradox: the art of political decision making. Rev. ed. New York: Norton. ISBN 0-393-97625-4. 
Barbora Burešová is a student in the doctoral degree programme at the Department of Political Science, Faculty of Social Science, Masaryk University, Joštova 10, 60200 Brno, Czech Republic, 414711@mail.muni.cz.

Stanislav Balík is a professor and works as a department head at the Department of Political Science, Faculty of Social Science, Masaryk University, Joštova 10, 602 oo Brmo, Czech Republic, balik@muni.cz. 